Jurnal Terapung : Ilmu - Ilmu Sosial , Vol. 3, No. 1, Maret 2021 ISSN: 2656-2928

\title{
KECEMASAN KOMUNIKASI DALAM PEMBELAJARAN PENDIDIKAN AGAMA ISLAM
}

\author{
Latifah \\ Akademi Kebidanan Yapkesbi Banjarbaru \\ Email: latifahhusien@yahoo.com
}

\begin{abstract}
ABSTRAK
Penelitian ini secara sistematis mengubah tingkah laku siswa dalam kecemasan komunikasi guru Pendidikan Agama Islam di Madrasah Ibtidaiyah Assalam Martapura. Memfokuskan pada perubahan tingkah laku dan membantu guru untuk melaksanakan perilaku yang baik kepada siswanya. Perubahan tingkah laku ini adalah kecemasan komunikasi pada siswa dalam proses pembelajaran yang dapat mengatasi rasa takut, bingung, dan kacau pikiran, tubuh gemetar, serta rasa demam panggung yang muncul dalam berkomunikasi.
\end{abstract}

Kata kunci: kecemasan komunikasi, pembelajaran Pendidikan Agama Islam

\begin{abstract}
This study systematically changes student behavior in the communication anxiety of Islamic Religious Education teachers at Madrasah Ibtidaiyah Assalam Martapura. Focusing on changing behavior and helping teachers to implement good behavior for their students. This behavior change is communication anxiety in students in the learning process which can overcome fear, confusion, and confusion of thought, body shaking, and stage fright that arises in communicating.
\end{abstract}

Keywords: communication anxiety, Islamic Religious Education learning

\section{PENDAHULUAN}

Guru dengan siswa merupakan dua komponen yang dapat dianalogikan seperti teori simbiosis mutualisme yaitu peran yang saling menguntungkan satu dangan yang lain. Jika salah satu komponen saja yang aktif tentunya tidak akan menghasilkan dampak yang maksimal. Sabagai timbal balik kemampuan komunikasi yang baik dari guru, siswa sebagai peserta didik hendaknya juga memiliki kemampuan berkomunikasi yang baik kepada guru. Interaksi komunikatif seperti inilah yang akan mendatangkan kenyamanan siswa dalam belajar dan guru dalam mengajar sehingga mendatangkan dampak positif salah satunya menambah kemauan siswa untuk aktif dalam mengikuti kegiatan belajar mengajar di sekolah seperti yang disampaikan oleh Robert E. Slavin. Guru yang efektif bukan hanya mengetahui pokok permasalahan siswa, tetapi juga dapat mengkomunikasikan pengetahuan yang dimilikinya kepada siswa. 
Kegiatan pendidikan yang dilakukan oleh guru tidak terlepas dari bagaimana proses komunikasi untuk penyampaian pesan dari komunikator kepada komunikan yang dapat menimbulkan efek tertentu. Dalam hal ini guru adalah seorang anggota masyarakat yang berkompeten dan memperoleh kepercayaan dari masyarakat dan atau pemerintah untuk melaksanakan tugas, fungsi dan peranannya, yakni mengajar, mendidik dan membimbing, atau dengan kata lain guru adalah salah satu komponen manusiawi dalam usaha pembentukan sumber daya manusia yang cerdas dan mempunyai akhlak mulia dalam melakukan perbuatannya. Sedangkan siswa adalah setiap orang yang menerima pengaruh dari seseorang atau sekelompok orang yang menjalankan kegiatan pendidikan. Keduanya baik guru maupun siswa merupakan unsur penting dalam proses pembelajaran, karena merekalah yang melakukan proses pembelajaran. Proses pembelajaran tidak akan terjadi jika tidak ada guru atau pun siswa.

Dengan melihat pengertian bahwa pendidikan adalah usaha sadar dari guru yang bertujuan untuk mengembangkan kualitas siswa, terkandung suatu makna bahwa proses yang dinamakan pendidikan itu tidak akan pernah berlangsung apabila tidak hadir guru dan siswa dalam rangkaian kegiatan belajar mengajar, sehingga bisa dikatakan bahwa guru dan siswa merupakan pilar utama terselenggaranya aktivitas pendidikan. Tenaga pendidik yang kurang berinteraksi dengan siswa secara akrab, menyebabkan proses pembelajaran kurang lancar dan siswa merasa jauh dari tenaga pendidik maka segan berpartisipasi secara aktif dalam belajar. Dalam berinteraksi, peran komunikasi sangatlah penting, artinya komunikasi interpersonal tenaga pendidik merupakan salah satu bentuk relasi tenaga pendidik dan siswa yang merupakan faktor yang mempengaruhi belajar. Belajar mengajar merupakan perilaku inti dalam proses pendidikan dimana anak didik dan pendidik berinteraksi. Interaksi belajar mengajar ditunjang oleh beberapa faktor lain dalam pendidikan antara lain: tujuan pendidikan, pendidik, anak didik, alam dan fasilitas pendidikan, metode mengajar, materi pelajaran dan lingkungan.

Berdasarkan uraian di atas dipaparkan bahwa telah ditemukan adanya beberapa permasalahan terkait dengan tidak efektifnya antara guru PAI dengan siswa. Adapun beberapa contoh permasalahan tersebut diantaranya kecemasan komunikasi guru dan siswa kurang intens pada saat pembelajaran. Ketika guru menerangkan mereka lebih tegang dan kelihatan cemas.

\section{METODE PENELITIAN}

Pada pendekatan ini, peneliti membuat suatu gambaran kompleks, meneliti kata-kata, laporan terinci dari pandangan responden, dan melakukan studi pada situasi yang alami. Penelitian kualitatif yang dilakukan adalah menggunakan induksi analitis (analytic induction) dan ekstrapolasi (extrpolation). Induksi analitis adalah satu pendekatan pengolahan data ke dalam konsep-konsep dan kateori-kategori (bukan frekuensi). Jadi simbol-simbol yang digunakan tidak dalam bentuk numerik, melainkan dalam bentuk deskripsi, yang ditempuh dengan cara merubah data ke formulasi. Sedangkan ekstrapolasi adalah suatu cara pengambilan kesimpulan yang dilakukan 
simultan pada saat proses induksi analitis dan dilakukan secara bertahap dari satu kasus ke kasus lainnya, kemudian dari proses analisis itu dirumuskan suatu pernyataan teoritis. Contohnya adalah observasi hanya mengamati masalah yang terjadi, kemudian wawancara untuk memberikan pertanyaan berkaitan dengan masalah yang akan diteliti, sehingga ditemukan hasil yang akurat berdasarkan temuan dilapangan dengan jawaban yang diperoleh.

\section{HASIL DAN PENELITIAN}

\section{Kecemasan Komunikasi dalam Pembelajaran Pendidikan Agama Islam}

Berdasarkan dari hasil observasi penelitian dilapangan, ditemukan bahwa kecemasan komunikasi guru PAI dengan siswa dalam proses pembelajaran di Madrasah Ibtidaiyah Assalam Martapura sudah berjalan dengan baik, hal ini dapat dilihat dari hasil observasi bahwa kecemasan komunikasi yang baik ditandai dengan kecemasan komunikasi guru yang dapat mengatasi rasa takut, bingung dan kacau pikiran dan demam panggung saat menjelaskan materi pelajaran dihadapan siswa di Madrasah Ibtidaiyah Assalam Martapura.

Berkenaan dengan kecemasan komunikasi guru PAI dengan siswa, maka dilakukan wawancara dengan guru PAI kelas IV sebagai informan 1 diruang guru, beliau mengatakan: "Beberapa keterampilan dalam berkomunikasi yang Ibu lakukan ketika dikelas dalam mengirimkan pesan agar menimbulkan pengertian dan keberanian untuk mengutarakan maksud dan tujuan diantaranya membuat pesan lengkap dan mudah dipahami, kemudian pesan-pesan nonverbal harus sesuai dengan pesan-pesan verbal.".

Berdasarkan informasi dari informan 1 mengungkapkan bahwa kecemasan komunikasi guru PAI dengan siswa dalam proses pembelajaran kecemasan komunikasi sudah cukup baik dalam mengurangi rasa takut dan pengertian atau pesan dapat dipahami, dikarenakan guru memilki keterampilan berkomunikasi dalam proses pembelajaran, sehingga siswa dapat dengan mudah dimengerti dan mengurangi rasa takut atas apa yang disampaikan, begitu pula dengan penjelasan materi PAI yang disampaikan gurunya dikelas.

Kemudian mewawancarai guru PAI IV sebagai informan 2 di ruang guru, beliau mengatakan: "Yang ibu lakukan di kelas dalam mengirimkan pesan agar menimbulkan pengertian yaitu pesan-pesan sebaiknya diulangi seperlunya, termasuk menggunakan lebih dari satu media untuk mengirimkan pesan yang sama, kemudian ibu berusaha mendapat umpan balik tentang pesan yang ditangkap oleh lawan komunikasi. Siswa diajarkan bagaimana memberikan pesan singkat untuk membiasakan kecemasan komunikasi untuk mengatasi rasa takut dan demam panggung”.

Berdasarkan informasi dari informan 2 mengungkapkan bahwa kecemasan komunikasi guru PAI dengan siswa dalam proses pembelajaran kecemasan komunikasi sudah cukup baik dalam mengurangi rasa takut dan dan demam panggung.

Selanjutnya mewawancarai guru PAI kelas V sebagai informan 3, di ruang kelas pada saat jam istirahat, beliau mengatakan: "Ketika saya mengajar dikelas saat 
pelajaran PAI, saya menyampaikan materi-materi pelajaran PAI dengan jelas apa yang disampaikan guru kepada siswa, karena ketika saya menjelaskan pelajaran, siswa sangat tertarik untuk memperhatian. Saya menjelaskan dengan selalu diiringi gerakan tubuh dan menggunakan begitu banyak media dalam menjelaskan materi pelajaran PAI. Saya juga memberikan umpan balik untuk bertanya guna mengurangi rasa takut siswa pada pelajaran PAI. Karena bagi saya menjawab soal tidak benarpun sudah bisa menjadi modal keberanian untuk mengatasi rasa grogi, takut dan demam panggung.

Berdasarkan informasi dari informan 3 mengungkapkan bahwa kecemasan komunikasi interpersonal guru dan siswa dalam proses pembelajaran kecemasan komunikasi sudah menunjukan keberanian untuk mengatasi rasa takut dan demam panggung, itu ditandai ketika siswa tersebut merasa mudah memahami penjelasan materi PAI dari gurunya, dikarenakan guru PAI tersebut ketika mengajar selalu diiringi dengan gerakan tubuh dan menggunakan begitu banyak media dalam berkomunikasi ketika menyampaikan pelajaran di kelas dan memberikan umpan balik bertanya atau menjawab pertanyaan guru untuk mengatasi rasa takut dan demam panggung.

Kemudian mewancarai guru PAI kelas VI yang berikutnya sebagai informan 4 di ruang guru, beliau mengatakan: "Saat saya menjelaskan materi pelajaran PAI, siswa merasa mudah memahami pelajaran PAI. Itu karena saya dapat menilai bagaimana caranya memudahkan siswa dalam memahami pelajaran PAI, diantaranya, saya menjelaskan pelajaran menggunakan kata-kata yang mudah dimengerti dan dapat dipahami, kemudian saya selalu memberikan contoh, berupa kisah nabi, kisah raja-raja, atau tokoh-tokoh yang menceritakan karakter yang menggambarkan materi pelajaran PAI yang sedang diajarkan. Selain itu untuk menguji keberanian dan mengatasi rasa takut dalam kecemasan komunikasi siswa, saya juga mengajak siswa untuk bertanya, bercerita dan menjawab pertanyaan".

Berdasarkan informasi dari informan 4 mengungkapkan bahwa kecemasan komunikasi guru dan siswa dalam proses pembelajaran kecemasan komunikasi sudah dapat menunjukan keberanian dalam mengatasi rasa takut dalam kecemasan komunikasi, karena guru PAI selalu menggunakan kata-kata yang mudah dimengerti dan memberikan contohnya sesuai materi pelajaran PAI dengan umpan balik kepada siswa.

Dari beberapa pernyataan yang telah dikemukakan oleh informan di atas maka dapat disimpulkan bahwa kecemasan komunikasi guru PAI dengan siswa dalam proses pembelajaran kecemasan komunikasi di Madrasah Ibtidaiyah Assalam Martapura memiliki tingkat kualitas komunikasi yang cukup baik dengan materi PAI yang mencakup keseluruhan Alquran Hadist, Aqidah Akhlak, Fiqih dam SKI yang ditandai salah satunya adalah mengatasi rasa takut dan demam panggung. Modal ini yang diterapkan oleh siswa untuk direalisasikan dalam berkomunikasi dengan orang lain. Demikian pula, guru dalam menyampaikan pelajaran dikelas dengan membuat pesan lengkap dan mudah dipahami, pesan nonverbal sesuai dengan pesan verbal, pesan diulangi seperlunya, menggunakan lebih dari satu media untuk mengirimkan pesan 
yang sama, dan mendapat umpan balik tentang pesan yang ditangkap oleh lawan komunikasi.

\section{KESIMPULAN}

Berdasarkan hasil penelitian dan pembahasan yang telah dipaparkan, maka kesimpulannya adalah: kecemasan komunikasi guru PAI dengan siswa dalam proses pembelajaran kecemasan komunikasi di Madrasah Ibtidaiyah Assalam Martapura terlihat saat guru PAI menyampaikan materi pelajaran yang mencakup keseluruhan Alquran Hadist, Aqidah Akhlak, Fiqih dam SKI yang ditandai salah satunya adalah mengatasi rasa takut dan demam panggung. Modal ini yang diterapkan oleh guru untuk direalisasikan dalam berkomunikasi dengan orang lain. Demikian pula, guru dalam menyampaikan pelajaran dikelas dengan membuat pesan lengkap dan mudah dipahami, pesan nonverbal sesuai dengan pesan verbal, pesan diulangi seperlunya, menggunakan lebih dari satu media untuk mengirimkan pesan yang sama, dan mendapat umpan balik tentang pesan yang ditangkap oleh lawan komunikasi.

\section{DAFTAR PUSTAKA}

Buseri, Kamrani. 2014. Dasar, Asas dan Prinsip dalam Pendidikan Islam. Banjamasin: Antasari Press

Blake, Reed dan Edwin O. Haroldson. 2003. Taksonomi Konsep Komunikasi. Terjemahan Hasan Bahanan. Surabaya: Papyrus.

Canggara, Hafied, 2004. Pengantar Ilmu Komuniaksi. Jakarta: Raja Grafindo Persada Djamarah, Syaiful Bahri. 2010. Guru dan Anak Didik. Jakarta: Reneka Cipta.

Fudyartanto. 2002. Psikologi Pendidikan. Yogyakarta: Global Pustaka Utama.

Latifah, L., Ngalimun, N., Andi Setiawan, M., \& Haji Harun, M. (2020). Kecakapan Behavioral Dalam Proses Pembelajaran PAI Melalui Komunikasi Interpersonal. Bitnet: Jurnal Pendidikan Teknologi Informasi, 5 (2), 36-42. https://doi.org/10.33084/bitnet.v5i2.1747

Mulyana, Deddy, 2008. Pengantar Ilmu Komunikasi. Bandung: Remaja Rosdakarya.

Mulyasa, 2004. Manajemen Berbasis Sekolah: Konsep, Strategi dan Implementasi. Bandung: Remaja Rosdakarya

Mulyono, Abdurrahman, 1999. Pendidikan Bagi Anak Berkesulitan Belajar. Jakarta: Rineka Cipta.

Slameto, 1995. Belajar dan Faktor-Faktor Yang Mempengaruhinya. Jakarta: Rineka Cipta.

Samana, 1999. Profesionalisme Ketenaga Pendidikan. Yogyakarta: Kanisius

Wiryanto, 2008. Pengantar Ilmu Komunikasi. Jakarta: Grasindo 